DOI: https://doi.org/10.24127/ajpm.v10i2.3241

\title{
ANALISIS KEMAMPUAN BERPIKIR KREATIF MATEMATIS: DAMPAK MODEL OPEN ENDED DAN ADVERSITY QUOTIENT (AQ)
}

\author{
Komarudin $^{1 *}$, Yulia Monica², Achi Rinaldi ${ }^{3}$, Novia Dwi Rahmawati ${ }^{4}$, Mutia $^{5}$ \\ ${ }^{1 *}, 2,3$ Universitas Islam Negeri Raden Intan Lampung, Lampung, Indonesia \\ ${ }^{4}$ Universitas Hasyim Asy'ari, Jombang, Indonesia \\ ${ }^{5}$ Institut Agama Islam Negeri Curup, Indonesia \\ * Jl. Endro Suratmin, Sukarame, Kec. Sukarame, Kota Bandar Lampung, Lampung 35131 \\ *E-mail: $\quad$ komarudin@radenintan.ac.id ${ }^{*}$
}

Received 13 November 2020; Received in revised form 10 June 2021; Accepted 28 June 2021

\begin{abstract}
Abstrak
Penelitian ini bertujuan untuk mengetahui pengaruh model pembelajaran Open Ended dan Adversity Quotient $(A Q)$ terhadap kemampuan berpikir kreatif matematis siswa. Populasi pada penelitian ini adalah seluruh siswa kelas XI SMA Gajah Mada Bandar Lampung. Sampel pada penelitian ini adalah siswa kelas XI IPA 1 sebagai kelas eksperimen, dan siswa kelas XI IPA 2 sebagai kelas kontrol. Jenis penelitian yang digunakan adalah Quasy Experimental Design dengan teknik pengambilan sampel Cluster Random Sampling. Teknik pengambilan data yang digunakan pada penelitian ini adalah tes dan angket. Tes berupa soal uraian untuk mengukur kemampuan berpikir kreatif matematis, dan angket untuk mengukur skor $A Q$. Angket yang digunakan adalah Adversity Response Profile (ARP). Uji hipotesis menggunakan uji anava dua jalan (Two Way Analysis of Variance) dengan taraf signifikansi 0,05. Hasil yang diperoleh dari penelitian ini adalah terdapat pengaruh model pembelajaran terhadap kemampuan berpikir kreatif matematis siswa, tidak terdapat pengaruh tipe $A Q$ terhadap kemampuan berpikir kreatif matematis siswa, dan tidak terdapat interaksi antara model pembelajaran dengan $A Q$ terhadap kemampuan berpikir kreatif matematis siswa.
\end{abstract}

Kata Kunci : Adversity quotient; $A Q$; berpikir kreatif matematis; model pembelajaran open ended.

\begin{abstract}
The study aims to know the impact of the open ended learning model on the student's creative thinking ability, the Adversity Quotient (AQ) influence on the student's creative thinking ability, and the interaction of the learning model and the AQ type to the student's creative thinking ability. The population in this study is all students of Senior High School Gajah Mada Bandar Lampung. The sample in this study is the class XI IPA 1 student as an experiment class, and the class XI IPA 2 as a control class. The kind of research used was Quasy Experimental Design with sample retrieval technique is Cluster Random Sampling. The data-retrieval techniques used in this study are tests and angkettes. Tests include descriptions to measure the mathematical creative thinking ability, and angket to measure the AQ score. The angket used is Adversity Response Profile (ARP). Hypothetical testing using anava testing two cell roads is not the same signification $<0,05$. The result of this study is that there is a learning model influence on a student's creative thinking ability, there is an AQ type influence on a student's creative mathematical thinking ability, and there is no interaction between the learning model and the AQ to the student's creative thinking ability.
\end{abstract}

Keywords: Adversity quotient; AQ; mathematical creative thinking; open ended learning model.

This is an open access article under the Creative Commons Attribution 4.0 International License 
DOI: https://doi.org/10.24127/ajpm.v10i2.3241

\section{PENDAHULUAN}

Di masa revolusi industri 4.0 keterampilan berpikir kreatif menjadi keterampilan esensial yang harus dimiliki oleh setiap lulusan pada setiap jenjang pendidikan (Lase, 2019; Zubaidah, 2018). Kreativitas didapatkan dari pola pikir kreatif atau berpikir kreatif (S. M. Dewi, Harjono, \& Gunawan, 2017; Harjono \& Rachman, 2018; Suwarsono \& Muhid, 2020). Kreativitas atau berpikir kreatif merupakan proses berpikir yang menghasilkan berbagai kemungkinan cara atau ide yang beragam (Diana 2018; Machromah, Riyadi, dan Usodo 2015)

Berpikir kreatif bisa dilatih salah satunya dengan memberikan stimulusstimulus yang dapat merangsang siswa untuk berpikir kreatif, pelajaran yang relevan dengan berpikir kreatif adalah pelajaran matematika. Fakta di lapangan, menunjukkan bahwa berpikir kreatif masih belum mendapatkan perhatian dalam pendidikan, banyak yang belum menyadari betapa pentingnya melatih berpikir kreatif (Nasution, 2017; Rahman, 2017; Wahyudi, Aminah, \& Sukarmin, 2018), Hasil penelitian yang telah dilakukan oleh (Mulyati, Suryani, \& Setiawan, 2019) menunjukkan bahwa model pembelajaran open ended memiliki pengaruh terhadap kemampuan berpikir kreatif. Kemampuan berpikir kratif matematis siswa masih rendah (Rahayu, Akbar, \& Afrilianto, 2019; Septi, Khusnunisa, \& Afrilianto, 2019). Karena kemampuan berpikir kreatif siswa kurang berkembang secara optimal, oleh karena itu dibutuhkan model pembelajaran yang dapat melatih dan mengembangkan kemampuan berpikir siswa (Karyanti \& Komarudin, 2017; Nur, 2016). Berdasarkan hal ini maka dirasa penting untuk dilakukan penelitian guna melihat pengaruh model pembelajaran open ended terhadap kemampuan berpikir kreatif.

Salah satu model pembelajaran yang dapat melatih berpikir kreatif siswa adalah model pembelajaran Open Ended (Akbar, Kodirun, \& Busnawir, 2017; Fatimah, 2017; Zaimah, 2019). Karena pada proses pembelajaran Open Ended siswa dituntut untuk mencari sendiri kemungkinan jawaban dari permasalahan yang diberikan (Hamdani, 2016; Hidayat \& Sariningsih, 2018; N. Lestari, Hartono, \& Purwoko, 2016; Ulandari, Putri, Ningsih, \& Putra, 2019). Selain itu model pembelajaran Open Ended sangat memfokuskan pada proses atau strategi penyelesaian permasalahan berdasarkan kemampuan siswa (K. D. Lestari, Suniasih, \& Manuaba, 2017; Magelo, Hulukati, \& Djakaria, 2020; Purwanto, Sukestiyarno, \& Junaedi, 2019; Sholikhah, Kartana, \& Utami, 2018).

Hal tersebut, menunjukkan bahwa model pembelajaran Open Ended memiliki kaitan dengan kemampuan berpikir kreatif matematis (M. Dewi, 2018; Palah, Maulana, \& Aeni, 2017; Zahro \& ISMAIL, 2019). Adapun langkah-langkah model pembelajaran Open Ended adalah sebagai berikut (Cahyani, Syaban, \& Ridha, 2019; Irawan \& Surya, 2017). Selanjutnya untuk lang-langkah dari model pembelajaran open ended dapat dilihat pada Gambar 1.

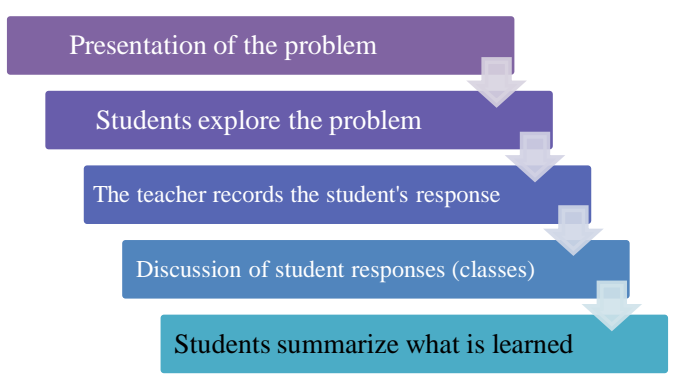

Gambar 1. Langkah-langkah model pembelajaran Open Ended 
Keberhasilan siswa tersebut juga dipengaruhi oleh beberapa faktor, diantaranya Adversity Quotient (AQ) (Baigar, 2018; Diana, 2018). Menurut (Septianingtyas \& Jusra, 2020; Setyaningsih, 2018) $A Q$ memiliki 3 kategori, yaitu tipe quitters (mereka yang berhenti) yaitu kelompok orang yang kurang mempunyai keinginan untuk menerima tantangan, tipe campers (mereka yang berkemah) yaitu kelompok orang yang tidak mau mengambil resiko, dan tipe climbers (mereka yang mendaki) yaitu kelompok orang yang memiliki keberanian dalam menghadapi masalah dan siap mengambil resiko.

Adapun penelitian sebelumnya yang mengkaji tentang model pembelajaran open ended telah banyak dilakukan. Adapun penelitian tersebut bertujuan untuk meningkatkan kemampuan berpikir kritis (Saputra \& Susilawati, 2019), komunikasi matematis siswa (Fadillah \& Fitraini, 2020), pemecahan masalah (Haryati \& Sari, 2018), koneksi matematis (Lubis, Harahap, \& Nasution, 2019), kemampuan penalaran matematis (Arfan, Abdullah, \& Bani, 2019), pemahaman konsep matematis (Andriani \& Revita, 2020).

Penelitian tentang AQ telah beberapa kali dilakukan diantaranya mengkaji tentang pengaruh AQ terhadap prestasi belajar matematika (Fadhila, Mudjiran, \& Gistituati, 2019; Nurfitriyanti, Rosa, \& Nursa'adah, 2020; US, 2015), terhadap pemecahan masalah (Yani, Ikhsan, \& Marwan, 2016), terhadap kemampuan berpikir kreatif (Nugroho, Wardono, Waluyo, \& Cahyono, 2019; Suastika \& Sesanti, 2019; Yanti \& Syazali, 2016). Adapun kebaruan dari penelitian ini yaitu untuk melihat pengaruh bersamaan antara model pembelajaran open ended dan adversity quotient terhadap kemampuan berpikir kreatif matematis siswa.

Berdasarkan uraian di atas, maka tujuan penelitian ini adalah untuk untuk melihat pengaruh model pembelajaran open ended dan adversity quotient terhadap kemampuan berpikir kreatif matematis siswa.

\section{METODE}

Jenis penelitian yang digunakan dalam penelitian ini adalah kuantitatif dengan desain penelitian Quasy Experimental Design dengan desain penelitian seperti pada Gambar 2.

\begin{tabular}{lll}
\hline Group & treatment & Post-test \\
\hline Experiment 1 & $\mathrm{X}_{1}$ & $\mathrm{O}_{1}$ \\
Experiment 2 & $\mathrm{X}_{2}$ & $\mathrm{O}_{2}$ \\
\hline
\end{tabular}

$X_{1}$ : model pembelajaran open ended

$X_{2}$ : model pembelajaran konvensional

Gambar 2. Desain penelitian

Populasi penelitian ini adalah seluruh siswa kelas XI SMA Gajah Mada Bandar Lampung berjumlah 157 siswa. Sampel kelas yang diambil pada penelitian adalah kelas XI IPA 1 sebagai kelas eksperimen yang berjumlah 30 siswa, dan kelasXI IPA 2 sebagai kelas kontrol yang berjumlah 30 siswa. Teknik pengambilan sampel dalam penelitian ini menggunakan teknik Cluster Random Sampling. Teknik pengumpulan data melalui tes dan angket. Tes yang akan digunakan dalam penelitian ini adalah dalam bentuk tes essay untuk mengetahui kemampuan berpikir kreatif matematis siswa. Sedangkan angket dilakukan untuk mengetahui skor $A Q$.

Adapun indikator yang digunakan pada penelitian ini dapat dilihat pada Tabel 1. 
DOI: https://doi.org/10.24127/ajpm.v10i2.3241

Tabel 1. Indikator Berpikir Kreatif

\begin{tabular}{ll}
\hline \multicolumn{1}{c}{ Indikator } & \multicolumn{1}{c}{ Keterangan } \\
\hline Kelancaran (Fluency) & Siswa mampu melahirkan banyak ide atau jawaban. \\
Keluwesan & Siswa mampu memberikan jawaban yang berbeda berdasarkan \\
(Flexibility) & pemikiran dari sudut pandang yang berbeda dan bervariasi \\
Kerincian & Siswa mampu memberikan jawaban yang jelas, serta mampu \\
(Elaboration) & menganalisis jawaban secara rinci. \\
Kerincian & Siswa mampu memberikan jawaban dengan tepat dan benar \\
(Elaboration) & yang sesuai dengan fakta serta berbeda dengan jawaban siswa \\
& lain \\
\hline
\end{tabular}

Teknik analisis data menggunakan uji prasyarat normalitas dan homogenitas. Uji hipotesis menggunakan uji anova dua jalan (Two Way Analysis of Variance), yang membandingkan perbedaan rata-rata antara kelompok yang telah dibagi pada dua variabel independen yaitu kelas eksperimen dan kontrol.

\section{HASIL DAN PEMBAHASAN}

Data hasil kemampuan berpikir kreatif matematis siswa pada materi barisan dan deret dapat dilihat pada Tabel 2.

Tabel 2. Data Hasil Kemampuan Berpikir Kreatif Matematis

\begin{tabular}{cccccccc}
\hline \multirow{2}{*}{ Kelas } & \multirow{2}{*}{$\boldsymbol{X}_{\text {maks }}$} & $\boldsymbol{X}_{\boldsymbol{m i n}}$ & \multicolumn{3}{c}{$\begin{array}{c}\text { Ukuran Tendensi } \\
\text { Sentral }\end{array}$} & \multicolumn{2}{c}{$\begin{array}{c}\text { Ukuran Varians } \\
\text { Kelompok }\end{array}$} \\
\cline { 4 - 8 } & & & $\overline{\boldsymbol{x}}$ & $\boldsymbol{M}_{\boldsymbol{e}}$ & $\boldsymbol{M}_{\boldsymbol{o}}$ & $\mathbf{R}$ & SD \\
\hline Eksperimen & 88 & 63 & 75,866 & 76 & 73 & 25 & 6,421 \\
Kontrol & 75 & 40 & 56,4 & 58 & 60 & 35 & 8,732 \\
\hline
\end{tabular}

Berdasarkan Tabel 2 secara lebih jelas data kemampuan berpikir kreatif matematis siswa disajikan pula dalam Gambar 4.

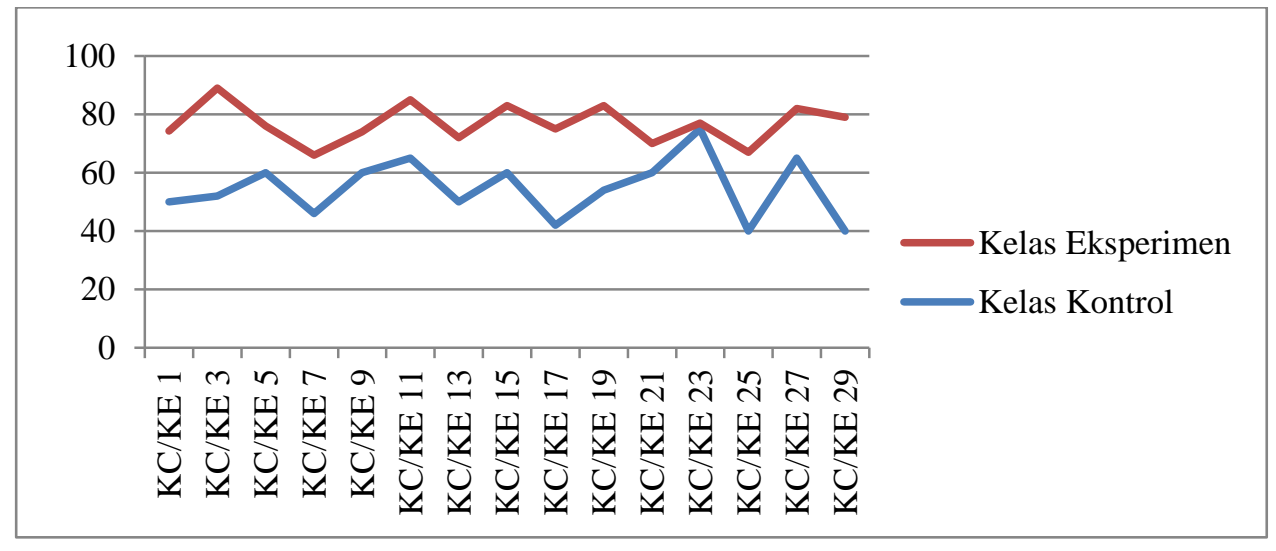

Gambar 4. Grafik kemampuan berpikir kreatif matematis

Berdasarkan Tabel 2 dan Gambar 4, terlihat bahwa nilai kemampuan berpikir kreatif matematis pada kelas eksperimen lebih tinggi dibandingkan dengan nilai kemampuan berpikir kreatif matematis pada kelas 
DOI: https://doi.org/10.24127/ajpm.v10i2.3241

kontrol. Data yang sudah diperoleh kemudian dilakukan uji prasyarat yaitu uji normalitas dan uji homogenitas.Uji normalitas data pada setiap kelas berasal dari populasi yang berdistribusi normal, serta memiliki varians yang homogen. Kemudian dilakukan uji hipotesis dengan uji anava dua jalan sel tak sama dengan hasil dapat dilihat pada Tabel 3.

Tabel 3 Hasil analisis varians dua jalan

\begin{tabular}{lccccc}
\hline \multicolumn{1}{c}{ Source } & $\begin{array}{c}\text { Type III Sum of } \\
\text { Squares }\end{array}$ & $\boldsymbol{d} \boldsymbol{f}$ & Mean Square & $\boldsymbol{F}$ & Sig. \\
\hline Model & 3314.055 & 1 & 3314.055 & 59.744 & 0.000 \\
AQ & 214.389 & 2 & 107.194 & 1.932 & 0.155 \\
Model * AQ & 167.888 & 2 & 83.944 & 1.513 & 0.229 \\
Error & 2995.409 & 54 & 55.471 & & \\
Total & 271508.000 & 60 & & & \\
\hline
\end{tabular}

Tabel 3 menunjukkan bahwa (1) nilai sig. model $=0,000<0,05$, maka $H_{0 A}$ ditolak, yang artinya terdapat pengaruh model pembelajaran open ended terhadap kemampuan berpikir kreatif matematis siswa. (2) nilai sig. $A Q=0,155>0,05, \quad$ maka $H_{0 B}$ diterima, yang artinya tidak terdapat pengaruh tipe $A Q$ terhadap kemampuan berpikir kreatif matematis siswa. (3) nilai sig. model $* A Q=0,229>0,05$, maka $H_{0 A B}$ diterima, yang artinya tidak terdapat interaksi antara model pembelajaran dengan $A Q$ terhadap kemampuan berpikir kreatif matematis siswa.

Hasil penelitian menunjukkan bahwa kemampuan berpikir kreatif siswa yang belajar dengan model open ended lebih baik Saat pembelajaran dengan model pembelajaran open ended siswa dituntut untuk dapat menyelesaikan permasalahan yang diberikan oleh guru berdasarkan cara yang siswa ketahui. Model pembelajaran open ended juga dilakukan secara berkelompok, jadi siswa lebih berperan aktif dalam pembelajaran (Lusiyana, Rohim, \& Rohman, 2017; Sari \& Yunarti, 2015; Solehuzain \& Dwidayati, 2017). Ciri khas model pembelajaran open ended yaitu guru memberikan soal terbuka berupa soal cerita yang berkaitan dengan materi barisan dan deret. Saat pemberian soal terbuka tersebut siswa dituntut untuk menyelesaikan permasalahan yang diberikan oleh guru berdasarkan cara yang siswa ketahui.

Proses pembelajaran kelas eksperimen yang berlangsung menggunakan model pembelajaran Open Ended, siswa akan lebih aktif saat mengikuti pelajaran Matematika. Karena saat pembelajaran guru memberikan suatu permasalahan nyata yang kemudian siswa berdiskusi secara kelompok (Sholikhah dkk., 2018). Dalam diskusi kelompok siswa berusaha untuk menyelesaikan permasalahan yang diberikan oleh guru sesuai dengan cara yang diketahui oleh siswa dan berusaha untuk menyelesaikan dengan beberapa kemungkinan jawaban sehingga dapat merangsang kemampuan berpikir kreatif matematis (Hoiriyah, 2019).

Sedangkan pada kelas kontrol digunakan model pembelajaran konvensional. Model pembelajaran konvensional adalah model pembelajaran yang di modifikasi oleh guru sehingga pembelajaran lebih dipusatkan kepada guru, sedangkan 
siswa hanya mendengarkan, menyimak, menanya, dan mencatat apa yang guru sampaikan. Sedangkan tidak semua siswa mempunyai keterampilan seperti itu. Pada saat mengerjakan permasalahan atau soal siswa cenderung enggan untuk bertanya kepada guru karena siswa belum erbiasa untuk lebih aktif dalam proses pembelajaran. Hal ini menyebabkan siswa mengalami kesulitan untuk memahami materi yang telah disampaikan.

Berdasarkan hal tersebut, kemampuan berpikir kreatif matematis siswa akan lebih baik jika diajarkan dengan menggunakan model pembelajaran Open Ended dibandingkan dengan model pembelajaran konvensional. Sesuai dengan hasil penelitian yang menunjukkan bahwa siswa yang mendapat model pembelajaran Open Ended lebih baik daripada siswa yang mendapat model pembelajaran konvensional. Berdasarkan hal tersebut, maka model pembelajaran Open Ended berpengaruh terhadap kemampuan berpikir kreatif matematis siswa (M. Dewi, 2018).

Ada kesesuaian dengan penelitian sebelumnya yang dilakukan oleh Caicy Magelo yang menyatakan bahwa model pembelajaran open ended berpengaruh terhadap kemampuan berpikir kreatif matematis siswa (Magelo dkk., 2020). Penelitian yang dilakukan oleh Rahmat Bahar juga menyatakan bahwa model pembelajaran open ended lebih baik secara signifikan dalam meningkatkan kemampuan berpikir kreatif dibandingkan dengan pembelajaran konvensional (Bahar, Anggo, \& Arapu, 2019). Selain berpengaruh terhadap kemampuan berpikir kreatif, model pembelajaran open ended juga berpengaruh terhadap kemampuan berpikir kritis dan kepercayaan diri siswa (Novtiar \& Aripin, 2017). Penelitian ini sejalan dengan penelitian yang dilakukan oleh Sri Mulyati dan Setiawan yang menyatakan bahwa model pembelajaran open ended berpengaruh terhadap kemampuan berpikir kritis, karena berpikir kreatif dan berpikir kritis merupakan bagian dari kemampuan berpikir tingkat tinggi (Mulyati dkk., 2019)

Selanjutnya untuk Adversity Quotient $(A Q)$ tidak terdapat perbedaan tipe AQ atau tidak terdapat pengaruh AQ terhadap kemampuan berpikir kreatif siswa baik siswa di kelas eksperimen maupun kelas kontrol antara siswa yang mendapat model pembelajaran open ended maupun siswa yang mendapat pembelajaran konvensional. Berbeda dengan penelitian yang telah dilakukan sebelumnya oleh Ratni Purwasih yang menyatakan bahwa terdapat pengaruh tipe $A Q$ terhadap kemampuan berpikir kreatif matematis siswa (Purwasih, 2019). Siswa dengan $A Q$ tipe campers dan quitters cenderung sulit untuk beradaptasi dengan model pembelajaran.

Selanjutnya untuk interaksi antara model pembelajaran open ended dengan Adversity Quotient ( $A Q$ ) didapat bahwa tidak terdapat interaksi antara model pembelajaran dengan tipe $A Q$ terhadap kemampuan berpikir kreatif matematis siswa. Karena siswa dengan $A Q$ tipe climbers sangat cocok diberikan model pembelajaran open ended (Aini \& Sri Sutarni, 2020), tetapi kurang cocok untuk siswa dengan $A Q$ tipe quitters, dikarenakan pembelajaran open ended menuntut siswa untuk menyelesaikan permasalahan berdasarkan pengetahuannya dan saat pembelajaran siswa pasti akan menemukan kesulitan (Munjayanah, 2016; Suciawati, 2020). Sedangkan siswa dengan $A Q$ tipe 
quitters dan campers cenderung sulit untuk bertadaptasi dengan model pembelajaran open ended (Ardiansyah, Junaedi, \& Asikin, 2018; Darojat \& Kartono, 2016). Dari hasil penelitian yang dilakukan yaitu tidak terdapat interaksi antara model pembelajaran dan tipe $A Q$ terhadap kemampuan berpikir kreatif matematis siswa. Hal ini kemungkinan disebabkan karena ada siswa yang tidak jujur saat mengisi angket serta siswa yang tidak mandiri atau bekerja sama dengan siswa lain dalam mengerjakan soal, maka berpengaruh pada ketidaksesuaian dengan hipotesis. Seharusnya terdapat interaksi antara model pembelajaran dengan tipe $A Q$ terhadap kemampuan berpikir kreatif matematis siswa.

\section{KESIMPULAN DAN SARAN}

Berdasarkan hasil penelitian dan didukung oleh beberapa teori, maka dapat disimpulkan bahwa terdapat pengaruh model pembelajaran open ended terhadap kemampuan berpikir kreatif matematis siswa, tidak terdapat pengaruh tipe $A Q$ terhadap kemampuan berpikir kreatif matematika siswa, dan tidak terdapat interaksi antara model pembelajaran dengan tipe $A Q$ terhadap kemampuan berpikir kreatif matematis siswa.

Berdasarkan simpulan di atas, terdapat beberapa saran diantaranya dalam pembelajaran open ended pembagian siswa didasarkan atas tingkat kecerdasan. Selain itu perlu dipersiapkan perangkat pembelajaran dengan baik. Untuk penelitian selajutnya dapat mencari model lain yang lebih mempengaruhi kemampuan berpikir kreatif matematis, ataupun menggunakan model yang sama dengan pengaruh yang lain, ataupun juga menggunakan model yang sama tetapi ditinjau dari kecerdasan yang lain.

\section{DAFTAR PUSTAKA}

Aini, A. B. N., \& Sri Sutarni, M. P. (2020). Analisis Kemampuan Berpikir Kreatif Siswa Dan Adversity Quotient Siswa Smp Kelas Viii Pada Materi Sistem Koordinat Kartesius Melalui Pembelajaran Open Ended. Universitas Muhammadiyah Surakarta.

Akbar, S., Kodirun, K., \& Busnawir, B. (2017). Pengaruh Pembelajaran Berbasis Masalah Dengan Pendekatan Open Ended Terhadap Kemampuan Berpikir Kreatif Matematik Ditinjau Dari Kemandirian Belajar Siswa SMA. Jurnal Pendidikan Matematika, 8(2), 117-128.

Andriani, L., \& Revita, R. (2020). Pengaruh Penerapan Pendekatan Open ended terhadap Kemampuan Pemahaman Konsep Matematis Berdasarkan Self Efficacy Siswa SMPN 2 Bangkinang Kota. JURING (Journal for Research in Mathematics Learning), 3(2), 125-132.

Angraini, C. D., Komarudin, K., \& Istihana, I. (2019). Pengaruh model diskursus multy reprecentacy (DMR) dengan pendekatan CBSA terhadap representasi matematis ditinjau dari motivasi belajar peserta didik. Prosiding Seminar Nasional Matematika dan Pendidikan Matematika, 2, 6575.

Ardiansyah, A. S., Junaedi, I., \& Asikin, M. (2018). Student's creative thinking skill and belief in mathematics in setting challenge based learning viewed by adversity quotient. Unnes Journal of Mathematics 
DOI: https://doi.org/10.24127/ajpm.v10i2.3241

Education Research, 7(1), 6170.

Arfan, S., Abdullah, I. H., \& Bani, A. (2019). Pengaruh Pendekatan Open-Ended terhadap

Kemampuan Penalaran

Matematis Siswa SMP pada Materi Garis dan Sudut. DeltaPi: Jurnal Matematika dan Pendidikan Matematika, 8(2).

Bahar, R., Anggo, M., \& Arapu, L. A. L. (2019). Pengaruh Penerapan Pendekatan Open-Ended Dalam Pembelajaran Matematika Terhadap Peningkatan Kemampuan Berpikir Kreatif Matematik Siswa Kelas VIII SMP Negeri 1 Konawe Selatan. Jurnal Penelitian Pendidikan Matematika, 6(1), 127-140.

Baigar, S. (2018). Adversity Quotient bagi Anak-Anak Sejak Dini. SANCTUM DOMINE: JURNAL TEOLOGI, 7(1), 85106.

https://doi.org/10.46495/sdjt.v7i 1.45

Cahyani, D. N., Syaban, M., \& Ridha, M. R. (2019). Peningkatan Kemampuan Berpikir Kreatif Matematis Melalui Pembelajaran Open-Ended Pada Siswa SMP. INTERMATHZO, 4(2), 78-86.

Darman, Y. F. (2018). Pengaruh Kemampuan Operasi Hitung Matematika Kemampuan Berpikir Divergen Dan Kecerdasan Linguistik Terhadap Hasil Belajar Matematika Siswa Kelas VIII SMP Negeri 1 Sengkang Kabupaten Wajo.

Darmani, J. W., \& Renaldi, A. (2018). Analisis Kemampuan Pemecahan Masalah Matematis: Dampak Model Pembelajaran Reciprocal Teaching Dengan
Fieldtrip. Desimal: Jurnal Matematika, 1(3), 373-380. https://doi.org/10.24042/djm.v1i 3.3108

Darojat, L., \& Kartono, K. (2016). Kemampuan Pemecahan Masalah Siswa Dalam Menyelesaikan Soal Open Ended Berdasarkan AQ Dengan Learning Cycle 7E. Unnes Journal of Mathematics Education Research, 5(1), 1-8.

Dewi, M. (2018). Pengaruh Pendekatan Open-Ended Terhadap

Kemampuan Berpikir Kreatif Dan Self Esteem Siswa Madrasah Aliyah Daar Al Uluum Kisaran. https://doi.org/10.31227/osf.io/t 3xvy

Dewi, S. M., Harjono, A., \& Gunawan, G. (2017). Pengaruh Model Pembelajaran Berbasis Masalah Berbantuan Simulasi Virtual Terhadap Penguasaan Konsep dan Kreativitas Fisika Siswa SMAN 2 Mataram. Jurnal Pendidikan Fisika Dan Teknologi, 2(3), 123-128. https://doi.org/10.29303/jpft.v2i 3.302

Diana, N. (2018). Mengembangkan Kemampuan Berpikir Kreatif dan Berpikir Logis Mahasiswa dengan Adversity Quotient dalam Pemecahan Masalah. Prosiding Seminar Nasional Matematika Dan Pendidikan Matematika (SNMPM), 2(1), 101-112.

Fadhila, S., Mudjiran, M., \& Gistituati, N. (2019). The Contribution of Adversity Quotient to Learning Outcomes of Students in Middle School and the Counseling Services Implication. Journal of 
DOI: https://doi.org/10.24127/ajpm.v10i2.3241

Educational and Learning Studies, 2(2), 65-70.

Fadillah, N., \& Fitraini, D. (2020). Pengaruh Penerapan Pendekatan Open-Ended terhadap Kemampuan Komunikasi Matematis berdasarkan Self Confidence Siswa Madrasah Aliyah Kampar. JURING (Journal for Research in Mathematics Learning), 3(1), 065-080.

Fatimah, F. (2017). Upaya Meningkatkan Kemampuan Berpikir Kreatif Siswa Sma Negeri 2 Bireuen Pada Materi Kalor Melalui Penerapan Model Pembelajaran Open-Ended Problem (Masalah Terbuka). Jurnal Pendidikan Almuslim, $5(2)$.

Firdausi, Y. N., Asikin, M., \& Wuryanto, W. (2018). Analisis Kemampuan Berpikir Kreatif Siswa Ditinjau dari Gaya Belajar pada Pembelajaran Model Eliciting Activities (MEA). PRISMA, Prosiding Seminar Nasional Matematika, 1, 239247.

Hamdani, A. S. (2016). Pengembangan Kreativitas Siswa Melalui Pembelajaran Matematika Dengan Masalah Terbuka (Open Ended Problem). Didaktis: Jurnal Pendidikan dan Ilmu Pengetahuan, $\quad 7(3)$. http://dx.doi.org/10.30651/didak tis.v7i3.257

Harjono, R., \& Rachman, A. (2018). Kreativitas Guru dalam Pembelajaran Ekstrakurikuler Musik Keroncong di SMP Negeri 1 Karangmoncol. Jurnal Seni Musik, 7(1), 34-47.

Haryati, F., \& Sari, A. W. (2018). Pengaruh Pembelajaran Dengan
Pendekatan Open Ended Terhadap Kemampuan Pemecahan Masalah Matematis Mahasiswa Pada Mata Kuliah Kalkulus FKIP UMSU. Intiqad: Jurnal Agama dan Pendidikan Islam, 10(1), 35-49.

Hidayat, W., \& Sariningsih, R. (2018). Kemampuan Pemecahan Masalah Matematis dan Adversity Quotient Siswa SMP Melalui Pembelajaran Open Ended. JNPM (Jurnal Nasional Pendidikan Matematika), 2(1), 109-118.

https://doi.org/10.33603/jnpm.v $2 \mathrm{i} 1.1027$

Hoiriyah, D. (2019). Kemampuan Berpikir Kreatif Mahasiswa dalam Menyelesaikan Soal-soal Open-Ended. Logaritma: Jurnal Ilmu-Ilmu Pendidikan Dan Sains, 7(02), 201-212. https://doi.org/10.24952/logarit ma.v7i02.2116

Irawan, A., \& Surya, E. (2017). Application of the Open ended Approach to Mathematics Learning in the Sub-subject of Rectangular. International Journal of Sciences: Basic and Applied Research (IJSBAR), 33(3), 270-279.

Karyanti, K., \& Komarudin, K. (2017). Pengaruh Model Pembelajaran Kumon Terhadap Pemahaman Matematis Ditinjau Dari Gaya Kognitif Peserta Didik Pada Mata Pelajaran Matematika Kelas VIII SMP Negeri Satu Atap 4 Pesawaran. Prosiding Seminar Nasional Matematika Dan Pendidikan Matematika, 1(1), 89-94.

Lase, D. (2019). Pendidikan di Era Revolusi Industri 4.0. SUNDERMANN: Jurnal Ilmiah 
DOI: https://doi.org/10.24127/ajpm.v10i2.3241

Teologi, Pendidikan, Sains, Humaniora dan Kebudayaan, 1(1), 28-43.

Lestari, K. D., Suniasih, N. W., \& Manuaba, I. B. S. (2017). Pengaruh Model Pembelajaran Open Ended Berbasis Keterampilan Menjelaskan Terhadap Kompetensi Pengetahuan IPA. Journal of Education Technology, 1(3), 169-175.

https://doi.org/10.23887/jet.v1i3. 12501

Lestari, N., Hartono, Y., \& Purwoko, P. (2016). Pengaruh Pendekatan Open-Ended Terhadap Penalaran Matematika Siswa Sekolah Menengah Pertama Palembang. Jurnal Pendidikan Matematika Sriwijaya, 10(1), 81-95.

Lubis, R., Harahap, T., \& Nasution, D. P. (2019). Pendekatan OpenEnded dalam Membelajarkan Kemampuan Koneksi Matematis Siswa. Mosharafa: Jurnal Pendidikan Matematika, 8(3), 399-410.

Lusiyana, A., Rohim, S., \& Rohman, F. (2017). Pengaruh Pendekatan Open-Ended untuk Meningkatkan Kemampuan Berpikir Kreatif Siswa pada Mata Pelajaran Fisika Berbasis Perangkat Lunak Modellus. JIPFRI (Jurnal Inovasi Pendidikan Fisika Dan Riset Ilmiah), 1(2), 65-74.

Magelo, C., Hulukati, E., \& Djakaria, I. (2020). Pengaruh Model Pembelajaran Open-Ended terhadap Kemampuan Berpikir Kreatif Matematik Ditinjau dari Motivasi Belajar. Jambura Journal of Mathematics, 2(1), $15-21$. https://doi.org/10.34312/jjom.v2 i1.2593

Mulyati, S., Suryani, Y., \& Setiawan, I. (2019). Pengaruh Penerapan Model Pembelajaran Open Ended Terhadap Kemampuan Berpikir Kritis Siswa Dengan Variabel Moderator Motivasi Belajar. Equilibrium: Jurnal Penelitian Pendidikan dan Ekonomi, 16(02), 123-132.

Munjayanah, R. (2016). Analisis Proses Berpikir Kreatif Matematis Siswa Kelas Viii Dalam Menyelesaikan Masalah OpenEnded Pada Pembelajaran Treffinger Ditinjau Dari Adversity Quotient Siswa. Universitas Negeri Semarang.

Nasution, P. R. (2017). Perbedaan Peningkatan Kemampuan Berpikir Kreatif Matematis dan Kemandirian Belajar Siswa pada Pembelajaran Berbasis Masalah dan Pembelajaran Konvensional di SMPN 4 Padangsidimpuan. Jurnal Paidagogeo, 2(1), 46-62.

Novtiar, C., \& Aripin, U. (2017). Meningkatkan Kemampuan Berpikir Kritis Matematis Dan Kepercayaan Diri Siswa Smp Melalui Pendekatan Open Ended. PRISMA, 6(2).

Nugroho, A. M., Wardono, W., Waluyo, S. B., \& Cahyono, A. N. (2019). Kemampuan Berpikir Kreatif ditinjau dari Adversity Quotient pada Pembelajaran TPACK. PRISMA, Prosiding Seminar Nasional Matematika, 2, 40-45.

Nur, I. R. D. (2016). Meningkatkan kemampuan berpikir kreatif matematis dan kemandirian belajar siswa dengan menggunakan model pembelajaran brain based 
DOI: https://doi.org/10.24127/ajpm.v10i2.3241

learning. JUDIKA (Jurnal

Pendidikan Unsika), 4(1).

Nurfitriyanti, M., Rosa, N. M., \&

Nursa'adah, F. P. (2020).

Pengaruh Kemampuan Berpikir

Kritis, Adversity Quotient dan

Locus of Control terhadap

Prestasi Belajar Matematika.

JKPM Kajian

Pendidikan Matematika), 5(2), 263-272.

Palah, S., Maulana, M., \& Aeni, A. N. (2017). Pengaruh Pendekatan Open-Ended Berstrategi M-Rte Terhadap Kemampuan Berpikir Kreatif Matematis Siswa Pada Materi Persegi Panjang. Jurnal Pena Ilmiah, 2(1), 1161-1170. https://doi.org/10.17509/jpi.v2i1 .11265

Purwanto, W. R., Sukestiyarno, Y. L., \& Junaedi, I. (2019). Proses Berpikir Siswa dalam Memecahkan Masalah Matematika Ditinjau dari Persepektif Gender. Prosiding Seminar Nasional Pascasarjana (PROSNAMPAS), 2(1), 894900.

Purwasih, R. (2019). Kemampuan Berpikir Kreatif Matematis Siswa Smp Dalam Menyelesaikan Soal Pemecahan Masalah Di Tinjau Dari Adversity Quotient Tipe Climber. AKSIOMA: Jurnal Program Studi Pendidikan Matematika, 8(2), 323-332. https://doi.org/10.24127/ajpm.v8 i 2.2118

Rahayu, E. L., Akbar, P., \& Afrilianto, M. (2019). Pengaruh Metode Mind Mapping Terhadap Strategi Thinking Aloud Pair Problem Solving Terhadap Kemampuan Berpikir Kreatif
Matematis. Journal on Education, 1(2), 271-278.

Rahman, A. (2017). Perbedaan Kemampuan Koneksi Matematis Dan Berpikir Kreatif Siswa Melalui Model Contextual Teaching And Learning Dan Problem Based Learning Pada Siswa Smp Negeri 1 Hinai. Unimed.

Rohmah, S., \& Rinaldi, A. (2019). Analisis Kemampuan Komunikasi Matematis: Dampak Kecerdasan Emosional Pada Materi Operasi Hitung Aljabar. Prosiding Seminar Nasional Matematika Dan Pendidikan Matematika, 2(1), 199-210.

Saputra, A. I., \& Susilawati, E. (2019). Pengaruh Model Pembelajaran Open-Ended Problem terhadap Kemampuan Berpikir Kritis dan Hasil Belajar Fisika Siswa SMAN 3 Kota Bima Tahun Pelajaran 2018/2019. Seminar Nasional Taman Siswa Bima, 1, 103-111.

Sari, I. P., \& Yunarti, T. (2015). Openended Problems untuk Mengembangkan Kemampuan Berpikir Kreatif Siswa. Seminar Nasional Matematika dan Pendidikan Matematika UNY.

Septi, D. V., Khusnunisa, M., \& Afrilianto, M. (2019). Motivasi Belajar Terhadap Kemampuan Berpikir Kreatif Matematis Pada Siswa. Journal on Education, 1(3), 498-506.

Septianingtyas, N., \& Jusra, H. (2020). Kemampuan Pemecahan Masalah Matematis Peserta Didik Berdasarkan Adversity Quotient. Jurnal Cendekia: Jurnal Pendidikan Matematika, 4(2), 657-672. 
DOI: https://doi.org/10.24127/ajpm.v10i2.3241

https://doi.org/10.31004/cendeki a.v4i2.263

Setyaningsih, R. (2018). Proses Metakognisi Mahasiswa Dengan Tipe Adversity Quotient (Aq) Quitters Dalam Memecahkan Masalah Matematika. Satya Widya, 34(2), 112-124. Https://Doi.Org/10.24246/J.Sw. 2018.V34.I2.P112-124

Sholikhah, Z., Kartana, T. J., \& Utami, W. B. (2018). Efektifitas Model Pembelajaran Open-Ended Terhadap Prestasi Belajar Matematika Ditinjau Dari Kreativitas Siswa. Jurnal Edukasi dan Sains Matematika, 4(1), 35-46. https://doi.org/10.25134/jesmat.v4i1.908

Solehuzain, S., \& Dwidayati, N. K. (2017). Kemampuan Berpikir Kreatif dan Rasa Ingin Tahu pada Model Problem-Based Learning dengan Masalah Open Ended. Unnes Journal of Mathematics Education Research, 6(1), 103-111.

Suastika, I. K., \& Sesanti, N. R. (2019). Analisis Tingkat Berfikir Kreatif Peserta Didik Dalam Menyelesaikan Soal Matematika Ditinjau Dari Adversity Quotient (AQ). RAINSTEK: Jurnal Terapan Sains \& Teknologi, 1(1), 34-39.

Suciawati, H. (2020). Meningkatkan Hasil Belajar Siswa Pada Pokok Bahasan Bilangan Pangkat Dua Dengan Model Pembelajaran Open-Ended. JURNAL MATHEMATIC

PAEDAGOGIC, 4(2), 153-162.

Suwarsono, R. M., \& Muhid, A. (2020).

Pengaruh Kegiatan Robotika Terhadap Keterampilan Berpikir Kreatif Siswa Usia SD.
JURNAL PENDIDIKAN DASAR NUSANTARA, 6(1), 136-146.

Ulandari, N., Putri, R., Ningsih, F., \& Putra, A. (2019). Efektivitas Model Pembelajaran Inquiry terhadap Kemampuan Berpikir Kreatif Siswa pada Materi Teorema Pythagoras. Jurnal Cendekia: Jurnal Pendidikan Matematika, 3(2), 227-237. https://doi.org/10.31004/cendeki a.v3i2.99

US, S. U. S. (2015). Pengaruh adversity qoutient terhadap prestasi belajar matematika. Formatif: Jurnal Ilmiah Pendidikan MIPA, 3(1).

Vandini, I. (2016). Peran Kepercayaan Diri terhadap Prestasi Belajar Matematika Siswa. Formatif: Jurnal Ilmiah Pendidikan MIPA, $5(3)$.

https://doi.org/10.30998/formatif .v5i3.646

Wahyudi, E. E., Aminah, N. S., \& Sukarmin, S. (2018). Pembelajaran Optika Geometri Melalui Problem Based Learning (Pbl) Ditinjau Dari Kemampuan Berpikir Kritis Siswa Dan Kemampuan Berpikir Kreatif Siswa SMA Kelas X Tahun 2014/2015. INKUIRI: Jurnal Pendidikan IPA, 6(3), 49-60. https://doi.org/10.20961/inkuiri. v6i3.17842

Yani, M., Ikhsan, M., \& Marwan, M. (2016). Proses berpikir siswa sekolah menengah pertama dalam memecahkan masalah matematika berdasarkan langkah-langkah Polya ditinjau dari adversity quotient. Jurnal Pendidikan Matematika Sriwijaya, 10(1), 42-57. 
DOI: https://doi.org/10.24127/ajpm.v10i2.3241

Yanti, A. P., \& Syazali, M. (2016). Analisis proses berpikir siswa dalam memecahkan masalah matematika berdasarkan langkah-langkah Bransford dan Stein ditinjau dari Adversity Quotient. Al-Jabar: Jurnal Pendidikan Matematika, 7(1), 63-74.

Zahro, K., \& ISMAIL. (2019). Profil Kemampuan Berpikir Kreatif Siswa SMP dalam Memecahkan Masalah Matematika OpenEnded Ditinjau dari Gaya Belajar Sensing dan Intuition. MATHEdunesa, 8(2). Diambil dari https://jurnalmahasiswa.unesa.ac .id/index.php/mathedunesa/articl e/view/28059

Zaimah, H. (2019). Penerapan Model Pembelajaran Open Ended Dalam Meningkatkan Kemampuan Berpikir Kreatif Siswa Pokok Bahasan Sistem Persamaan Linear Dua Variabel Di Kelas VIIIG MTS Negeri 2 Mojokerto. Inovasi-Jurnal Diklat Keagamaan, 13(2), 9-21.

Zubaidah, S. (2018). Mengenal 4C: Learning and innovation skills untuk menghadapi era revolusi industri 4.0. 2nd Science Education National Conference, 13. 